\title{
Antioxidants and Protein Carbonyls in Bronchoalveolar Lavage Fluid of Children: Normal Data
}

\author{
BETTINA C. SCHOCK, IAN S. YOUNG, VANESSA BROWN, PATRICK S. FITCH, \\ ROBERT TAYLOR, MICHAEL D. SHIELDS, AND MADELEINE ENNIS \\ Department of Clinical Biochemistry, Queen's University of Belfast, Belfast BT12 6BJ, U.K. [B.C.S., \\ I.S.Y., V.B., P.S.F., M.E.]; Department of Child Health, Queen's University of Belfast, Belfast BT12 6BJ, \\ U.K. [M.D.S.]; Department of Anaesthetics, The Royal Belfast Hospital for Sick Children, \\ Belfast BT12 6BJ, U.K. [R.T.]
}

\begin{abstract}
Antioxidant-oxidant imbalances in bronchoalveolar lavage fluid (BAL) are thought to contribute to oxidative stress in respiratory disease. However, normal reference ranges for BAL antioxidants and oxidized proteins in children are not available. In this study, we recruited 124 children attending for elective surgery for a noninflammatory condition; 83 were nonasthmatic, nonatopic (N) and 41 were nonasthmatic, atopic (NA). A nonbronchoscopic lavage was performed and ascorbate, uric acid, $\alpha$-tocopherol, and protein carbonyl (as a measure of oxidative damage) concentrations were determined in BAL fluid. The $95 \%$ reference range was $0.112-1.897 \mu \mathrm{mol} / \mathrm{L}$ for ascorbate, $0.149-$ $2.163 \mu \mathrm{mol} / \mathrm{L}$ for urate, $0.0029-0.066 \mu \mathrm{mol} / \mathrm{L}$ for $\alpha$-tocopherol, and $0.280-4.529 \mathrm{nmol} / \mathrm{mg}$ for protein carbonyls in BAL fluid. Age, gender, and exposure to environmental tobacco smoke did not affect the concentration of ascorbate, urate, $\alpha$-tocopherol, or protein carbonyls. However, in multiple linear regression analyses, the type of home heating (glass-fronted fires or oil-fired central heating) was found to influence ascorbate and urate concentrations in the BAL fluid $(\beta$-coefficient for ascorbate: $0.445, p=0.031$; for urate: $0.114, p=0.001)$. There was no
\end{abstract}

\section{ABSTRACT}

significant difference between the N and NA group in BAL fluid concentrations of ascorbate, urate, or protein carbonyls. The $\alpha$-tocopherol concentration was significantly increased in the NA group ( $p=0.037)$. Uric acid and $\alpha$-tocopherol concentrations in BAL fluid and serum were not correlated. Intriguingly, serum and BAL ascorbate concentrations were significantly correlated $(r=0.297, p=0.018, n=63)$, which may offer an explanation for why supplementing the diet with vitamin $\mathrm{C}$ can improve asthma symptoms. Further studies will investigate the role of BAL antioxidant concentrations in children with inflammatory respiratory diseases. (Pediatr Res 49: 155-161, 2001)
BAL, bronchoalveolar lavage
Abbreviations
ETS, environmental tobacco smoke
GFF, glass-fronted fire
$\mathbf{N}$, nonasthmatic, nonatopic
NA, nonasthmatic, atopic
OFCH, oil-fired central heating

The epithelial lining fluid of the lungs contains relatively high concentrations of low molecular weight antioxidants such as ascorbic acid, uric acid, reduced glutathione (GSH), and $\alpha$-tocopherol. They provide a first defense against inhaled exogenous oxidants such as $\mathrm{SO}_{2}, \mathrm{NO}_{2}, \mathrm{CO}$, and $\mathrm{O}_{3}$ and against

Received November 11, 1999; accepted July 5, 2000.

Correspondence: Professor Madeleine Ennis, Department Clinical Biochemistry, Institute of Clinical Science, The Queen's University of Belfast, Grosvenor Road, Belfast BT12 6BJ, Northern Ireland, U.K.

Supported by grants from the National Asthma Campaign, U.K., Northern Ireland Mother and Baby Appeal, and the Deutscher Akademischer Austauschdienst (DAAD), Germany. endogenously produced oxidants (1-3). The increasing incidence of asthma, seen especially in children over the last two decades (4), has been linked to a reduced intake of antioxidant vitamins such as ascorbate, carotenoids, and $\alpha$-tocopherol (5). Recently, Kelly et al. have found reduced ascorbate and $\alpha$-tocopherol concentrations in the respiratory lining fluid of adults with mild asthma when compared with normal controls (6). An imbalance between antioxidants and oxidants in the epithelial lining fluid of the lung is thought to contribute to oxidative stress in respiratory disease (6).

To determine the effect of respiratory diseases on the oxidant/antioxidant balance, it is important to know the concen- 
trations of antioxidants in the respiratory lining fluid of normal children. To date, concentrations of antioxidants in BAL fluid have only been reported for adults $(7,8)$ and ventilated newborn infants $(9-11)$. Reports on oxidized proteins in BAL fluid are also rare $(12,13)$. For ethical reasons, fiberoptic bronchoscopy is generally not available as a research tool in children. Heaney et al. used a nonbronchoscopic lavage technique to enable access to the airways of children attending for elective surgery (14). However, normal reference values for the concentration of low molecular weight antioxidants or oxidatively modified proteins do not exist either for adults or for children.

Endogenous factors such as exposure to ETS and air pollution may affect the concentrations of antioxidants in the epithelial lining fluid. Parental smoking increases the risk of respiratory illness in infancy and childhood (15). Cotinine measurements have shown that children whose parents smoke absorb the constituents of the ETS $(16,17)$. In smokers, ascorbate concentrations are increased in BAL fluid and alveolar macrophages (7), whereas $\alpha$-tocopherol concentrations are reduced (18). Morrison et al. found an increase in epithelial permeability, numbers of neutrophils, and total antioxidant capacity in BAL fluid of smokers (19).

Epidemiologic studies have shown that ambient air pollution is associated with increased mortality and hospital admission for respiratory symptoms (20-22). An acute reduction in lung function correlates with increased air pollution (23-25). Many pollutants such as $\mathrm{NO}_{2}, \mathrm{CO}$, and particulate matter have been found at high concentrations indoors. These pollutants increase during cooking, smoking, and burning of solid fuels, especially in houses with poor ventilation $(26,27)$. Some studies have also established a link between the type of heating used in the home and respiratory symptoms or reduced lung function (24, 28). In Northern Ireland, homes are often heated by means of GFF. A pilot study revealed that children living in houses heated with GFF were at higher risk of wheezing, current use of asthma medication, and doctor-diagnosed asthma compared with those living in homes heated by OFCH (29).

Dietary supplementation with vitamins (ascorbic acid, $\alpha$-tocopherol, and $\beta$-carotene) has some positive effect on symptoms and lung function (30).

There is a lack of information on antioxidant concentrations in BAL fluid from children. We therefore determined a normal reference range for the concentrations of ascorbate, urate, and $\alpha$-tocopherol and oxidized proteins in BAL fluid of children without respiratory disease and relate these to simultaneously obtained serum concentrations. We also aimed to determine the effect of age, gender, exposure to ETS, and type of home heating on these parameters.

\section{METHODS}

Subjects. Eighty-three N and 41 NA children, who were otherwise well, attending for elective surgery for a noninflammatory condition were recruited from the Royal Belfast Hospital for Sick Children. A detailed respiratory and allergy history, which also included information on parental smoking and type of home heating (GFF or OFCH) (31), and serum IgE measurements were used as previously described (14) to cat- egorize the children. Children with a personal history of atopy (e.g. atopic eczema or allergic rhinitis) or elevated $\operatorname{IgE}$ but without respiratory involvement were classified as NA (31). Children with a past history of any episode of wheezing, problem coughing, or other chronic respiratory symptoms were excluded. All children were considered free from recent upper respiratory tract infections. Written informed consent was obtained from the parents or guardians of each recruited subject before surgery. The study was approved by the Ethics Committee of The Queen's University of Belfast.

$\boldsymbol{B} \boldsymbol{A} \boldsymbol{L}$. BAL procedure followed a standard protocol as described elsewhere (14). Briefly, after the induction of anesthesia and intubation, a sterile 8-French graduated neonatal suction catheter was inserted through the endotracheal tube and wedged in a distal airway. Lavage was performed with a single $20-\mathrm{mL}$ aliquot of normal saline and the lavage fluid was immediately aspirated. A $500-\mu \mathrm{L}$ aliquot of the sample was incubated with a final concentration of $10 \mathrm{mmol} / \mathrm{L} \mathrm{Na}_{2}$ EDTA and $35 \mathrm{mmol} / \mathrm{L}$ DTT for $30 \mathrm{~min}$ on ice and in the dark. The sample was then centrifuged $\left(200 \times g, 5 \mathrm{~min}, 4^{\circ} \mathrm{C}\right)$ and the supernatant frozen at $-70^{\circ} \mathrm{C}$ until assayed.

Ascorbic acid and uric acid in BAL fluid. A modification of the HPLC method with electrochemical detection described by Chevion et al. (32) was used. Standards of both antioxidants $(0.25-2 \mu \mathrm{mol} / \mathrm{L})$ were prepared in $0.9 \%$ sodium chloride with a final concentration of $10 \mathrm{mmol} / \mathrm{L} \mathrm{Na}_{2}$ EDTA and $35 \mathrm{mmol} / \mathrm{L}$ DTT to generate a standard curve. The detection limit (mean blank $+2.6 \cdot \mathrm{SD})$ was $0.106 \mu \mathrm{mol} / \mathrm{L}$ for ascorbate $(n=3)$ and $0.030 \mu \mathrm{mol} / \mathrm{L}$ for urate $(n=3)$. The interassay coefficient of variation was $7.8 \%$ for ascorbic acid $(n=33)$ and $9.1 \%(n=$ 28) for uric acid.

$\alpha$-Tocopherol in BAL fluid. $\alpha$-Tocopherol was measured after extraction from the sample (33) by HPLC with electrochemical detection according to the method described by Ikenova et al. (34). Samples were reconstituted in ethanol in a volume $1 / 10$ th of the volume initially used to give a 10 times concentration. Oxidation was performed at a working potential (E) of $+0.85 \mathrm{~V}$ (range pA). The mobile phase consisted of methanol containing $0.05 \mathrm{~mol} / \mathrm{L}$ sodium perchlorate and $0.1 \%$ pyridine, and the separation was performed at a flow rate of 1.8 $\mathrm{mL} / \mathrm{min} . \alpha$-Tocopherol standard dilutions $(0,0.0125,0.025$, $0.05,0.25,0.5$, and $2.5 \mu \mathrm{mol} / \mathrm{L}$ ) were used to calculate the $\alpha$-tocopherol concentration in the samples. The detection limit (mean blank $+2.6 \cdot \mathrm{SD}$ ) was $0.028 \mu \mathrm{mol} / \mathrm{L}(n=5)$ and the interassay variation was $12.1 \%(n=24)$.

Protein carbonyls in BAL fluid. Carbonyl groups in proteins were determined in supernatant using an ELISA as described by Buss et al. $(35,36)$. Briefly, after derivatization of carbonyl groups with dinitrophenylhydrazine (DNPH) and adsorption to the wells of an ELISA plate (96-well, Maxisorb Immunoplate, Nunc, Roskilde, Denmark), a biotinylated anti-DNPH antibody (rabbit anti human, Molecular Probes Europe BV, Leiders, The Netherlands) was used as a capture antibody that subsequently was visualized by addition of a horseradish peroxidase labeled streptavidine biotin complex and a substrate [hydrogen peroxide and ortho-phenylenediamine (OPD)]. The absorbance was measured at $\lambda=590-405 \mathrm{~nm}$ and the concentration calculated from a standard curve. 
Antioxidants in serum. The lipid-soluble vitamins retinol, $\alpha$-tocopherol, $\alpha$-carotene, $\beta$-carotene, and lycopene were measured by HPLC with UV detection as described by Ito et al. (33), with the assay standardized against the National Institute of Standard Reference Material 968b. Interassay coefficients of variation were $<5 \%$ for retinol and $\alpha$-tocopherol and $<10 \%$ for carotenoids. Ascorbate and urate were determined in serum samples after deproteination in 5\% metaphosphoric acid using the method of Chevion et al. (32). The detection limit, was 6.21 $\mu \mathrm{mol} / \mathrm{L}$ for ascorbate $(n=5)$ and $12.26 \mu \mathrm{mol} / \mathrm{L}$ for urate $(n=$ $5)$. The interassay coefficient of variation was $10.9 \%$ for ascorbic acid $(n=24)$ and 7.7\% $(n=16)$ for uric acid. Thus, ascorbate plus dehydroascorbate was measured in BAL fluid, whereas ascorbate only was measured in serum. Previous studies have indicated that only $2 \%$ of the ascorbate in serum is in the dehydroascorbate form (37).

Protein determination. Total protein concentrations were quantified using the commercially available BioRad ${ }^{\circledR}$ kit (BioRad Laboratories Ltd., Hemel Hampstead, UK).

Data analyses. Descriptive statistics were used to calculate the median, interquartile range (IQR), lower (2.5th and 5th), and upper (95th and 97.5th) centiles for each antioxidant and oxidized protein. As there is no consensus for reporting reference intervals, we also quote the antilogarithm of the logarithmic mean (geometric mean, GM) and the reference limits produced by back transforming the upper and lower limits of the mean $\pm 1.96 \mathrm{SD}$. We have expressed our reference intervals in concentration per milliliter lavage fluid as recommended by the European Respiratory Society (ERS) Task Force on BAL in children (38). The data in Table 4 are given for comparison with other reports correcting for total protein in lavage fluid. As each antioxidant and oxidized proteins were not normally distributed, we studied the effect of age on these values by simple linear regression of the logarithmic concentration against age (years) and the slope of the regression line ( $\beta$-coefficient) recorded. Chi-square test was used to test for differences in the proportion between subgroups (N/NA) with exposure to the potential risk factors. Multiple linear regression on the logarithmic transformed data were used to determine whether age (years), gender (female/male), serum antioxidant concentration $(\mu \mathrm{mol} / \mathrm{L})$, atopy (N/NA), exposure to parental ETS (yes/no), and type of home heating (GFF/OFCH) had statistically significant and independent effects on BAL antioxidant levels.

Statistical comparisons were performed using MannWhitney $\mathrm{U}$ test (unpaired samples). A $p$ value of $<0.05$ was regarded as statistically significant. All statistical analyses were carried out using SPSS (Version 8.0) for Windows (SPSS, Chicago, IL, U.S.A.) and GraphPad Prism ${ }^{\circledR}(\mathrm{GraphPad}$ Software Inc., San Diego, CA, U.S.A.).

\section{RESULTS}

Subjects. A total of 124 children were included in the study. Their mean age was 7.2 y (range 1.6-12.6 y), of whom 68 were male. Eighty-three were N (mean age $7.0 \pm 0.3 \mathrm{y}$, range $1.6-12.0 \mathrm{y} ; 18$ male) and 41 were classified as NA (mean age $7.5 \pm 0.4 \mathrm{y}$, range $3.2-12.6 \mathrm{y} ; 18$ male). Of the 122 children where information on exposure to ETS was available, 68 were exposed to parental ETS and 48 had mothers who smoked (data available only for 65 subjects). The two subgroups (N and NA) did not differ significantly from each other with regard to age ( $p=0.34)$, proportion of home heating with GFF $(p=0.122)$, or proportion of exposure to parental smoking $(p=0.09)$ (Table 1).

There was no statistical difference in the volume return (median and range) between the two groups [N: $36.9 \%(12 \%-$ $65 \%)$ and NA: $36.5 \%(15 \%-62.5 \%), p=0.947$; overall: $36.8 \%(12.5 \%-65 \%)]$. The protein concentration in the lavage fluid (median and range) overall was 50.21 (1.99-328.7) $\mu \mathrm{g} / \mathrm{mL}$ [49.4 (3.5-328.7) $\mu \mathrm{g} / \mathrm{mL}$ for the $\mathrm{N}$ group and 59.8 (1.99-185.4) $\mu \mathrm{g} / \mathrm{mL}$ the NA group]. No statistical difference between the groups was observed $(p=0.145)$.

Normal reference intervals for BAL fluid antioxidants and protein carbonyls. BAL fluid concentrations of ascorbate, urate, $\alpha$-tocopherol, and protein carbonyls of all children are summarized in Table 2 and include the upper and lower reference intervals. Due to the small return volume, ascorbate and urate could only be determined in 73 BAL samples, $\alpha$-tocopherol in only 66 samples, and protein carbonyls in 102 samples (Table 2). Simple linear regression showed that the logarithmic mean concentrations of the antioxidants and the oxidized proteins did not vary significantly with age (years). The $\beta$-coefficients against age were $-0.042(p=0.725)$ for ascorbate, $-0.201(p=0.088)$ for urate, $0.208(p=0.093)$ for $\alpha$-tocopherol, and $0.173(p=0.083)$ for protein carbonyls. The overall median and the $95 \%$ reference intervals for each antioxidant and protein carbonyls of all children plotted against age are shown in Figures 1-4. There was no significant difference between the N and NA group in BAL fluid concentrations of ascorbate, urate, or protein carbonyls (Table 3). The $\alpha$-tocopherol concentration was significantly increased in the NA group ( $p=0.037$ ) (Table 3).

In a multiple regression analysis, when adjusted for all factors simultaneously — age (years), gender (female/male), serum concentration of the antioxidant $(\mu \mathrm{mol} / \mathrm{L})$, atopy $(\mathrm{N} / \mathrm{NA})$,

Table 1. Characteristics of children included in the study

\begin{tabular}{lccc}
\hline & $\begin{array}{c}\text { All children } \\
\text { studied }\end{array}$ & $\begin{array}{c}\text { Nonasthmatic, } \\
\text { nonatopic (N) }\end{array}$ & $\begin{array}{c}\text { Nonasthmatic, } \\
\text { atopic (NA) }\end{array}$ \\
\hline Number & 124 & 83 & 41 \\
Age (years) & $7.1 \pm 0.3$ & $7.0 \pm 0.3$ & $7.5 \pm 0.4$ \\
Male/Female & $68 / 56$ & $49 / 34$ & $19 / 22$ \\
Total serum IgE & & $18.5 \pm 2.5$ & $160.1 \pm 43.5$ \\
& & $(1.99-107.0)$ & $(2.0-890.0)$ \\
Exposure to ETS & 68 & & \\
$\quad$ Parental* & 48 & 26 & 27 \\
$\quad$ Maternal $\dagger$ & & & \\
Homes heating method & 37 & 21 & 16 \\
$\quad$ GFF & 64 & 47 & 17 \\
OFCH & & & \\
\hline
\end{tabular}

Characteristics of all children included in the study. The two subgroups (N and NA) did not differ significantly from each other in age $(p=0.34)$ or proportion $\left(\chi^{2}=3.1\right.$ for type of heating, $p>0.05$ and $\chi^{2}=0.39$ for exposure to ETS, $p>0.05$ ). The total serum $\operatorname{IgE}$ (mean \pm SEM (range) $\mathrm{kU} / \mathrm{L}$ ) was significantly elevated in children with atopy (NA), $p<0.001$.

* Data available only for 122 subjects.

$\dagger$ Data available only for 65 subjects. 
Table 2. Summary statistics and calculated reference intervals for antioxidant concentrations and oxidized proteins in BAL fluid

\begin{tabular}{lcccc}
\hline & Ascorbate & Urate & $\alpha$-Tocopherol & $\begin{array}{c}\text { Protein } \\
\text { carbonyls }\end{array}$ \\
\hline $\begin{array}{l}\text { Number } \\
\text { BAL concentration }\end{array}$ & $\begin{array}{c}73 \\
(\mu \mathrm{mol} / \mathrm{L})\end{array}$ & $\begin{array}{c}73 \\
(\mu \mathrm{mol} / \mathrm{L})\end{array}$ & $\begin{array}{c}66 \\
(\mu \mathrm{mol} / \mathrm{L})\end{array}$ & $\begin{array}{c}102 \\
(\mathrm{nmol} / \mathrm{mg})\end{array}$ \\
Median & 0.418 & 0.511 & 0.0169 & 1.243 \\
IQR & $0.250-0.699$ & $0.371-0.693$ & $0.0160-0.027$ & $0.808-1.709$ \\
Minimum- & $0.106-1.985$ & $0.120-1.519$ & $0.0028-0.073$ & $0.280-5.011$ \\
$\quad$ maximum & & & & \\
5th centile & 0.122 & 0.221 & 0.0037 & 0.36 \\
95th centile & 1.608 & 1.519 & 0.0473 & 3.079 \\
2.5th centile & 0.112 & 0.149 & 0.0029 & 0.280 \\
97.5th centile & 1.897 & 2.163 & 0.0660 & 4.529 \\
GM & 0.441 & 0.517 & 0.0166 & 1.184 \\
GM - 1.96 SD & 0.110 & 0.173 & 0.0043 & 0.368 \\
GM + 1.96 SD & 1.794 & 1.543 & 0.0647 & 3.808 \\
\hline
\end{tabular}

The geometric mean $(\mathrm{GM}) \pm 1.96 \mathrm{SD}$ was obtained from the mean \pm 1.96 $\mathrm{SD}$ of the logarithm concentration and back transforming the mean and each of the upper and lower limits. IQR, interquartile range.

and exposure to parental ETS (yes/no) - only the type of home heating $(\mathrm{GFF} / \mathrm{OFCH})$ was significantly and independently associated with changes in BAL fluid concentrations of ascorbate and urate. Using a stepwise approach to the model, both types of home heating ( $\beta$-coefficient: $0.120, p=0.005$ ) and the serum concentration ( $\beta$-coefficient: $0.445, p=0.031$ ) remained statistically significant for ascorbate whereas for urate only the type of home heating remained statistically significant ( $\beta$-coefficient: $0.114, p=0.001$ ).

Serum antioxidants. The median and range of all serum antioxidants determined are summarized in Table 5. Lipidsoluble antioxidants ( $\alpha$-tocopherol, retinol, $\alpha$-carotene, and lycopene) and water-soluble antioxidants (ascorbate and urate) were similar in the two subgroups (Table 5).

$\beta$-Carotene was significantly reduced in the NA group compared with $\mathrm{N}$ children $[0.293(0.017-1.778) \mu \mathrm{mol} / \mathrm{L}$ versus $0.169(0.043-1.178) \mu \mathrm{mol} / \mathrm{L}, p=0.002]$.

Correlations between serum and BAL fluid measurements. In all children studied, ascorbate concentrations in BAL fluid showed a weak but statistically significant association with the

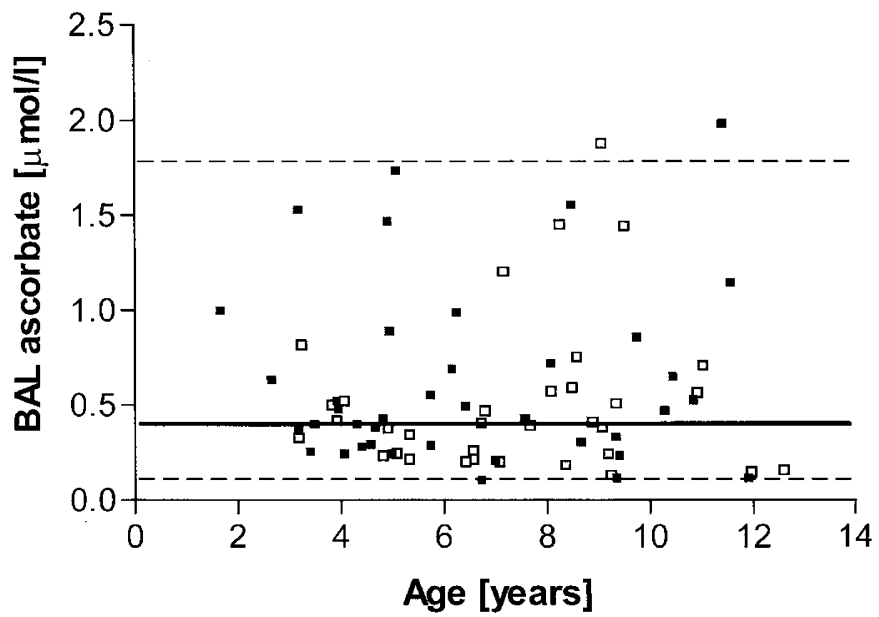

Figure 1. The median (-) and 95th reference intervals (---, 2.5th and 97.5th centile) for ascorbate concentrations $(\mu \mathrm{mol} / \mathrm{L})$ in BAL fluid of all children studied plotted against age ( $\square, \mathrm{N}$ children; $\square$, NA children).

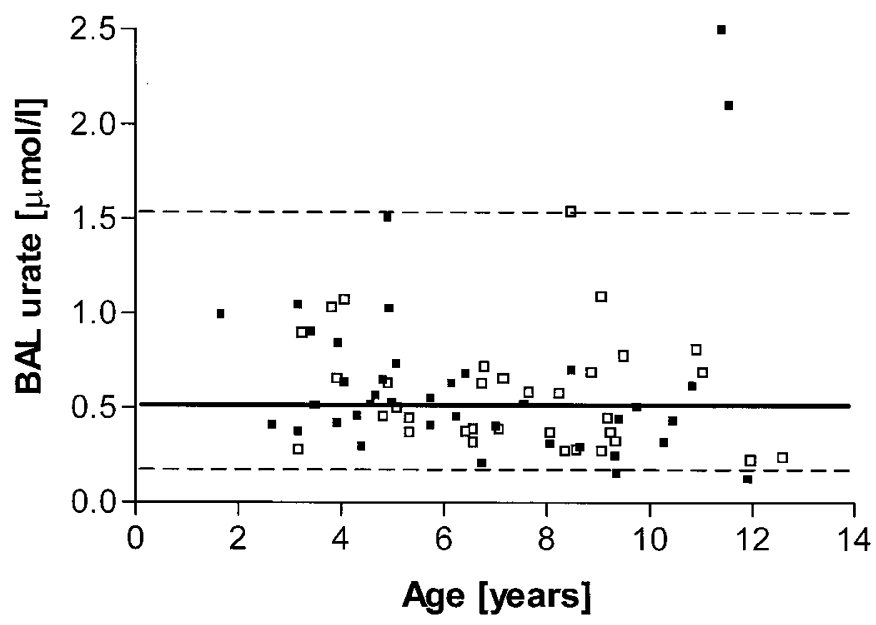

Figure 2. The median (-) and 95th reference intervals (---, 2.5th and 97.5th centile) for urate concentrations ( $\mu \mathrm{mol} / \mathrm{L}$ ) in BAL fluid of all children studied plotted against age ( $\square$, N children; $\square$, NA children).

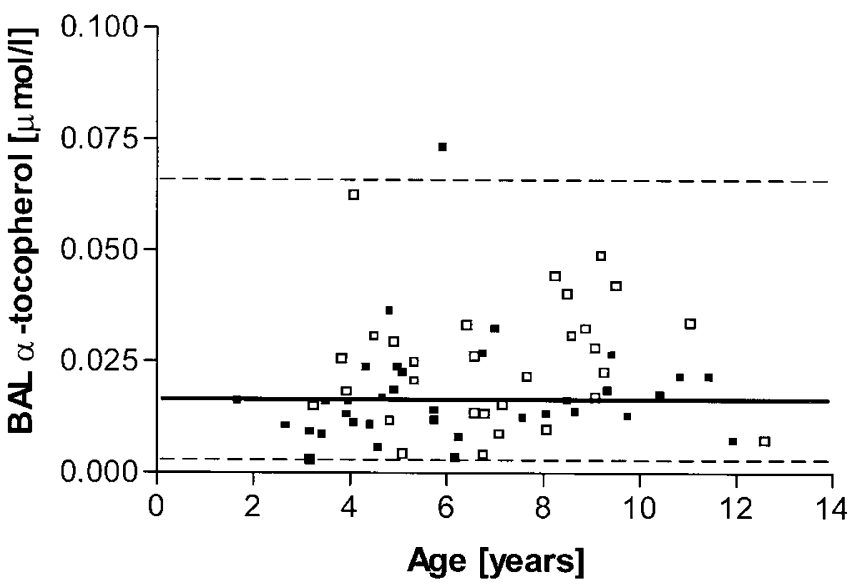

Figure 3. The median $(-)$ and 95 th reference intervals (---, 2.5th and 97.5th centile) for $\alpha$-tocopherol concentrations ( $\mu \mathrm{mol} / \mathrm{L})$ in BAL fluid of all children studied plotted against age ( $\square$, N children; $\square$, NA children).

respective serum concentration $(r=0.297, p=0.018, n=63)$ (Fig. 5). Uric acid and $\alpha$-tocopherol concentrations in BAL fluid and serum were not correlated $(r=-0.002, p=0.989$, $n=59$ for urate; $r=-0.082, p=0.528, n=62$ for $\alpha$-tocopherol).

BAL fluid antioxidant concentrations correlated significantly with protein concentration (ascorbate: $\mathrm{r}=0.497, p<$ $0.0001, n=73$; urate: $\mathrm{r}=0.590, p<0.0001, n=73$; $\alpha$-tocopherol: $r=0.462, p=0.0024, n=66$ ). Both watersoluble antioxidants (ascorbate and urate) also correlated significantly with each other $(r=0.65, p<0.0001, n=73)$ (Fig. 6). Protein carbonyls [nmol/mg protein] correlated weakly but significantly with ascorbate and urate concentrations in BAL fluid (ascorbate: $r=0.42, p=0.001$; urate: $r=0.342, p=$ 0.006 ; both $n=64$ ).

\section{DISCUSSION}

This study presents the first report on concentrations of antioxidants and oxidatively modified proteins in BAL fluid of a relatively large number of healthy children without respira- 


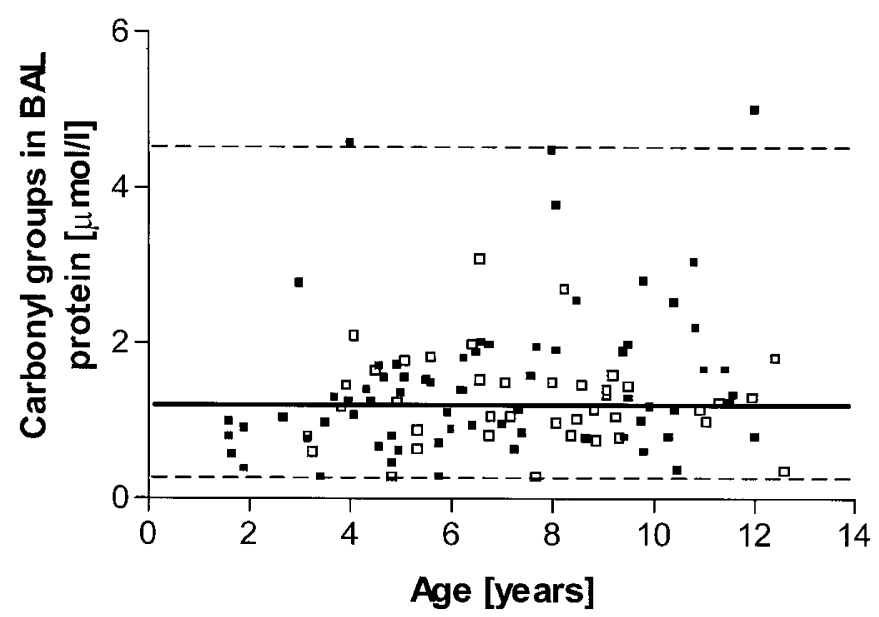

Figure 4. The median (-) and 95th reference intervals (---, 2.5th and 97.5th centile) for concentrations of protein carbonyls $[\mathrm{nmol} / \mathrm{mg}]$ in BAL fluid of all children studied plotted against age ( $\square$, N children; $\square$, NA children).

Table 3. BAL concentrations of antioxidants and protein carbonyls

\begin{tabular}{lccc}
\hline & $\begin{array}{c}\text { Nonasthmatic, } \\
\text { nonatopic (N) }\end{array}$ & $\begin{array}{c}\text { Nonasthmatic } \\
\text { atopic (NA) }\end{array}$ & $p$ Value \\
\hline Ascorbate $(\mu \mathrm{mol} / \mathrm{L})$ & & & \\
$\quad$ Median & 0.467 & 0.399 & 0.243 \\
$\quad$ Range & $0.106-1.985$ & $0.126-1.881$ & \\
Upper 95th centile & 1.732 & 1.555 & \\
Urate $(\mu \mathrm{mol} / \mathrm{L})$ & & & \\
Median & 0.518 & 0.475 & 0.723 \\
$\quad$ Range & $0.120-2.480$ & $0.228-1.539$ & \\
Upper 95th centile & 2.104 & 1.202 & \\
$\alpha$-Tocopherol $(\mu \mathrm{mol} / \mathrm{L})$ & & & \\
Median & 0.0160 & 0.0228 & 0.037 \\
Range & $0.0028-0.0734$ & $0.0028-0.0625$ & \\
Upper 95th centile & 0.0439 & 0.0543 & \\
Protein carbonyls (nmol/mg) & & & \\
Median & 1.259 & 1.140 & 0.442 \\
$\quad$ Range & $0.280-5.011$ & $0.280-3.086$ & \\
$\quad$ Upper 95th centile & 4.137 & 2.810 & \\
\hline
\end{tabular}

BAL concentrations of the antioxidants ascorbate, urate, $\alpha$-tocopherol, and protein carbonyls in BAL fluid of all children. Results are given as median and range. All children: ascorbate, urate $\mathrm{n}=73 ; \alpha$-tocopherol $\mathrm{n}=66$; carbonyls $\mathrm{n}=102 . \mathrm{N}$ : ascorbate, urate $\mathrm{n}=39 ; \alpha$-tocopherol $\mathrm{n}=35$; carbonyls $\mathrm{n}=69$. NA: ascorbate, urate $\mathrm{n}=34 ; \alpha$-tocopherol $\mathrm{n}=31$; carbonyls $\mathrm{n}=33$. Statistical comparisons between $\mathrm{N}$ and NA were made using the MannWhitney $U$ test.

tory disease. The antioxidants assessed in this study (ascorbate, urate, $\alpha$-tocopherol) together with glutathione represent the main antioxidants in the epithelial lining fluid of the lung and provide a first defense against inhaled and endogenous oxidants (1-3). Previous information on antioxidants and oxidized proteins in BAL fluid comes from animal work (39) or human studies in adults $(7,8,39)$.

The $95 \%$ reference range was $0.112-1.897 \mu \mathrm{mol} / \mathrm{L}$ for ascorbate, $0.149-2.163 \mu \mathrm{mol} / \mathrm{L}$ for urate, $0.0029-0.066$ $\mu \mathrm{mol} / \mathrm{L}$ for $\alpha$-tocopherol, and $0.280-4.529 \mathrm{nmol} / \mathrm{mg}$ for protein carbonyls in BAL fluid (Table 2).

Compared with data available from normal adults, the uncorrected levels of ascorbate in children are similar to those found in adults $(7,40)$; although some studies have reported higher concentrations (mean: $1.75 \mu \mathrm{mol} / \mathrm{L}$ and $1.7 \mu \mathrm{mol} / \mathrm{L})(7$,
Table 4. BAL concentrations of antioxidants and protein carbonyls

\begin{tabular}{lll}
\hline & $\begin{array}{c}\text { Nonasthmatic, } \\
\text { nonatopic (N) }\end{array}$ & $\begin{array}{c}\text { Nonasthmatic } \\
\text { atopic (NA) }\end{array}$ \\
\hline Ascorbate (nmol/mg protein) & & \\
$\quad$ Median & 11.89 & 7.07 \\
$\quad$ Range & $1.99-160.52$ & $2.11-27.76$ \\
$\quad$ Upper 95th centile & 79.38 & 23.71 \\
Urate (nmol/mg protein) & & \\
$\quad$ Median & 11.82 & 9.07 \\
$\quad$ Range & $3.85-109.92$ & $4.19-31.56$ \\
$\quad$ Upper 95th centile & 66.45 & 30.01 \\
$\alpha$-Tocopherol (nmol/mg protein) & & \\
$\quad$ Median & 0.294 & 0.361 \\
$\quad$ Range & $0.045-4.455$ & $0.057-1.130$ \\
$\quad$ Upper 95th centile & 2.485 & 1.114 \\
Protein carbonyls (pmol/mL) & & \\
$\quad$ Median & 64.14 & 82.21 \\
$\quad$ Range & $13.24-271.75$ & $4.29-319.74$ \\
$\quad$ Upper 95th centile & 218.30 & 309.34 \\
\hline
\end{tabular}

BAL concentrations of the antioxidants ascorbate, urate, $\alpha$-tocopherol, and protein carbonyls in BAL fluid of all children. Results are given as median and range. All children: ascorbate, urate $\mathrm{n}=73 ; \alpha$-tocopherol $\mathrm{n}=66$; carbonyls $\mathrm{n}=102 . \mathrm{N}$ : ascorbate, urate $\mathrm{n}=39 ; \alpha$-tocopherol $\mathrm{n}=35$; carbonyls $\mathrm{n}=69$. NA: ascorbate, urate $\mathrm{n}=34 ; \alpha$-tocopherol $\mathrm{n}=31$; carbonyls $\mathrm{n}=33$.

8). Urate concentrations found in BAL fluid of children in this study were lower than those in adults. Slade et al. reported urate concentrations of (mean) $1.23 \mu \mathrm{mol} / \mathrm{L}$ (39) and Van der Vliet et al. calculated the urate concentration in epithelial lining fluid at about $200 \mu \mathrm{mol} / \mathrm{L}$ in adults (7). $\alpha$-Tocopherol concentrations in BAL fluid of children were in accordance with levels found in healthy adult volunteers [mean: 0.026 $\mu \mathrm{mol} / \mathrm{L}$ in BAL fluid (39) and $0.7 \mu \mathrm{mol} / \mathrm{L}$ calculated for epithelial lining fluid (7)]. Concentrations of protein carbonyls were lower in children than those found in adults. Lenz et al. reported (mean) 5.3 and $14.1 \mathrm{nmol} / \mathrm{mg}$ protein in BAL fluid of normal nonsmoking adults $(12,41)$.

$\alpha$-Tocopherol is located in the membrane bilayer of the cells and its distribution depends on the presence of extracellular lipids such as surfactant or lipoproteins. Indeed, $\alpha$-tocopherol is secreted by alveolar type II cells together with surfactant lipids (42). Ascorbate and urate are water-soluble and have antioxidant function in the extracellular space.

The relation of these antioxidants to their corresponding serum concentrations is not known. In this study, total ascorbate was the only antioxidant, which showed a significant positive correlation with its serum concentration. Van der Vliet et al. did not find a correlation between serum and BAL fluid concentrations of ascorbate, suggesting a secreting and/or recycling mechanism in the respiratory tract rather then passive diffusion (7). However, the small sample numbers $(n=12)$ might be a limiting factor for these conclusions (7). Vitamin supplementation (ascorbic acid, $\alpha$-tocopherol, and $\beta$-carotene) (43) has some beneficial effect on lung function in adults. An epidemiologic study in children showed an association between lung function measurements $\left(\mathrm{FEV}_{1}\right)$ and intake of fresh fruit, an association that was stronger in subjects with wheeze than in nonwheezers (44). Although in their study, plasma vitamin $\mathrm{C}$ levels were not significantly related to fresh fruit intake, $\mathrm{FEV}_{1}$, and wheeze (44), the results of our study do 
Table 5. Water-soluble and lipid-soluble antioxidants in serum

\begin{tabular}{|c|c|c|c|c|}
\hline & All children studied & $\begin{array}{c}\text { Nonasthmatic, nonatopic } \\
\text { (N) }\end{array}$ & $\begin{array}{c}\text { Nonasthmatic, atopic } \\
\text { (NA) }\end{array}$ & $p$ Value \\
\hline Ascorbate $(\mu \mathrm{mol} / \mathrm{L})$ & $75.66(23.24-151.72)$ & $81.56(23.24-151.72)$ & $71.96(26.79-140.54)$ & 0.203 \\
\hline Urate $(\mu \mathrm{mol} / \mathrm{L})$ & $283.9(128.2-436.6)$ & $285.2(65.25-144.19)$ & $273.8(128.2-403.9)$ & 0.499 \\
\hline Retinol $(\mu \mathrm{mol} / \mathrm{L})$ & $0.807(0.279-1.839)$ & $0.800(0.279-1.839)$ & $0.835(0.283-1.791)$ & 0.833 \\
\hline$\alpha$-Carotene $(\mu \mathrm{mol} / \mathrm{L})$ & $0.033(0.009-0.324)$ & $0.034(0.009-0.324)$ & $0.026(0.009-0.129)$ & 0.074 \\
\hline$\beta$-Carotene $(\mu \mathrm{mol} / \mathrm{L})$ & $0.274(0.017-1.778)$ & $0.293(0.017-1.778)$ & $0.169(0.043-1.178)$ & 0.002 \\
\hline
\end{tabular}

Water-soluble and lipid-soluble antioxidants in serum. All children: ascorbate $\mathrm{n}=64$; urate $\mathrm{n}=60$; all others $\mathrm{n}=112$. N: ascorbate $\mathrm{n}=36$; urate $\mathrm{n}=33$; all others $n=77$. NA: ascorbate $n=28$; urate $n=27$; all others $n=35$. Results are given as median (range). Statistical comparisons between $N$ and NA were made using the Mann-Whitney $U$ test.

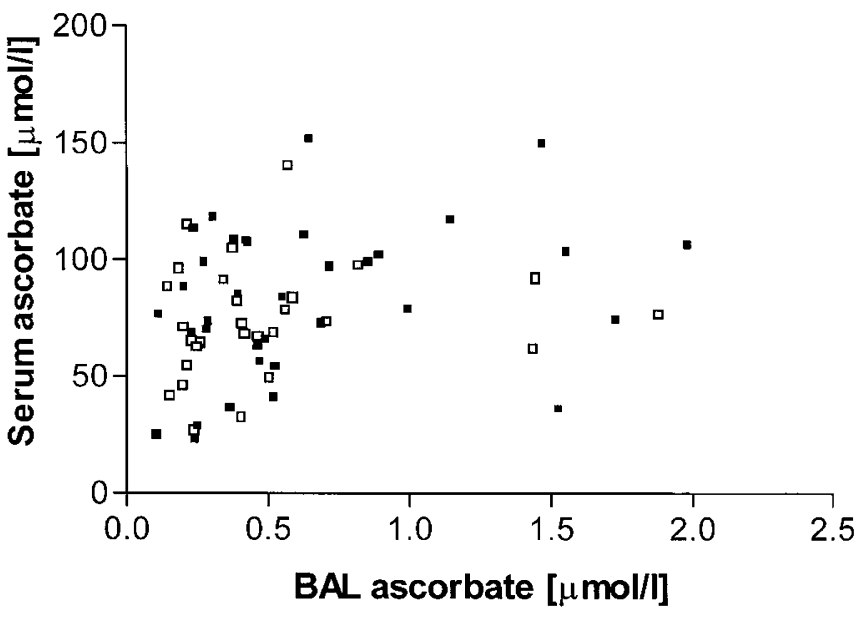

Figure 5. Correlation between the concentration of ascorbate $(\mu \mathrm{mol} / \mathrm{L})$ in serum and BAL fluid ( $r=0.297, p=0.018, n=63)$ using Spearman's correlation coefficient ( $\square, \mathrm{N}$ children; $\square$, NA children).

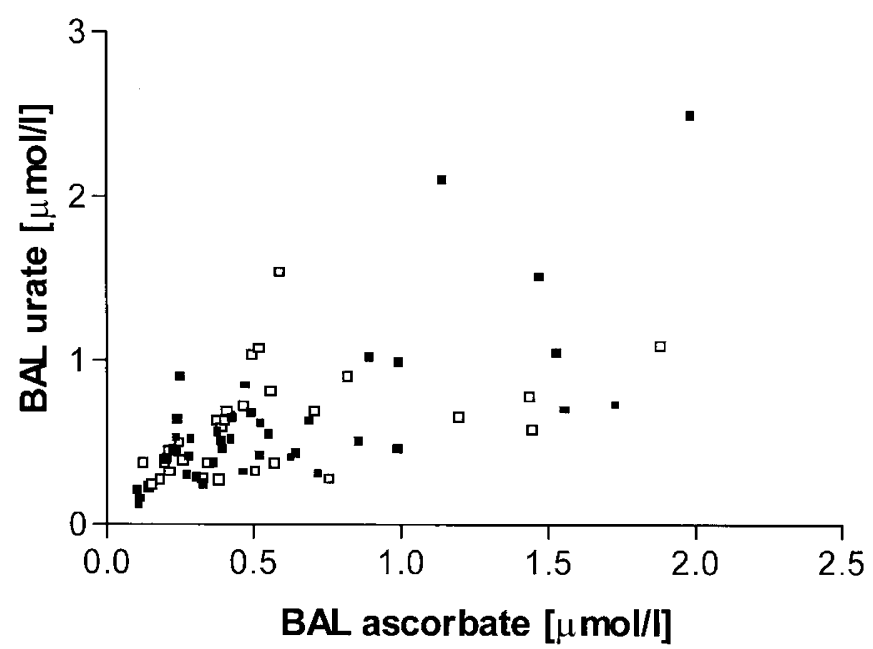

Figure 6. Correlation between the water-soluble antioxidants ascorbate $(\mu \mathrm{mol} / \mathrm{L})$ and urate $(\mu \mathrm{mol} / \mathrm{L})$ in BAL fluid $(r=0.649, p<0.0001, n=73)$ using Spearman's correlation coefficient ( $\square$, N children; $\square$, NA children).

suggest that there is a moderate association between serum and BAL fluid concentrations of ascorbate. Only around $2 \%$ of the total serum ascorbate is oxidized to dehydroascorbate (37). To accurately determine ascorbate without acidifying the sample, we measured total ascorbate (dehydroascorbate and ascorbate) in BAL fluid and ascorbate only in serum. Our results indicate that it may be possible to increase the ascorbate concentration in the epithelial lining fluid by increasing the ascorbate intake through the children's diet.

In the airways, damage to the epithelium due to the action of oxidants, inflammatory mediators, or allergens leads to protein influx and further inflammation (2). BAL fluid ascorbate and urate concentrations in this study correlated significantly with each other and both antioxidants correlated with total protein concentration, suggesting that, even in noninflammatory conditions, in children ascorbate and urate are brought into the BAL fluid with the influx of interstitial fluid. Epithelial permeability may also explain the significant positive correlation of antioxidants (ascorbate and urate) with the concentration of oxidized proteins. A higher permeability of the epithelium in children compared with adults has been shown (45). Serum concentrations of lipid-soluble antioxidants are in accordance with Homnick et al., although the concentrations of lycopene and retinol were higher compared with the data presented in this study (46). However, in our study no information was obtained about the dietary intake of vitamins.

To evaluate confounding factors, which may significantly alter the concentrations of antioxidants and oxidized proteins in BAL fluid, multiple regression analysis was applied. In the regression model only the type of home heating was significantly and independently associated with changes in BAL fluid concentrations of ascorbate and urate. In our study, two types of home heating predominate (GFF and $\mathrm{OFCH}$ ). A pilot study on 299 children showed an association between respiratory symptoms and living in houses heated by GFF (29). This is in agreement with other studies that have shown an increased risk of pneumonia, bronchiolitis, and wheezing bronchitis and an increased incidence of more severe respiratory illness in children exposed to open fires and gas cookers in the home (28, 47). A small preliminary study revealed that the concentration of $\mathrm{PM}_{10}$ particles is significantly increased in houses with GFF during times when the heating is switched on compared with the concentration found when the heating is not in use (unpublished results). Particles and $\mathrm{SO}_{2}$ may act as irritants, which stimulate sensory nerves and subsequently lead to airway hyperresponsiveness, whereas $\mathrm{O}_{3}$ and $\mathrm{NO}_{2}$ affect airway cells and lead to release of inflammatory mediators (3). Inhaled particles with a median aerodynamic diameter of $<10 \mu \mathrm{m}$ $\left(\mathrm{PM}_{10}\right)$ have been shown to have oxidant capacity (48). More recent studies have shown that free radical activity of black carbon and $\mathrm{PM}_{10}$ particles in suspension is derived from 
transition metals released into solution $(49,50)$. It is thus possible that exposure to an environmental pollutant such as $\mathrm{PM}_{10}$ particles in homes heated by GFF causes the reduction in ascorbate and urate concentrations in BAL fluid.

In summary, the present study is the first to evaluate normal levels of the antioxidants in BAL fluid of children. Age, gender, and exposure to ETS did not affect the concentration of ascorbate, urate, $\alpha$-tocopherol, or protein carbonyls. However, the type of home heating was found to reduce ascorbate and urate in the epithelial lining fluid of children. Intriguingly, serum and BAL ascorbate concentrations were significantly correlated, which may offer an explanation for why supplementing the diet with vitamin $\mathrm{C}$ can improve asthma symptoms $(51,52)$. Further studies will investigate the role of BAL antioxidant concentrations in children with inflammatory respiratory diseases and the possible effect of antioxidant supplementation.

\section{REFERENCES}

1. Kelly FJ, Mudway I, Krishna MT, Holgate ST 1995 The free radical basis of air pollution: focus on ozone. Respir Med 89:647-656

2. Cross CE, Van der Vielt A, O’Neill C, Louie S, Halliwell B; 1994 Oxidants, antioxidants, and respiratory tract lining fluids. Environ Health Perspect 102(suppl 10):185-191

3. Barnes PJ 1995 Air pollution and asthma: molecular mechanisms. Mol Med Today $1: 149-155$

4. Burr ML, Butland BK, King S, Vaughan WE 1989 Changes in asthma prevalence: two surveys 15 years apart. Arch Dis Child 64:1452-1456

5. Seaton A, Godden DJ, Brown K 1994 Increase in asthma: a more toxic environmen or a more susceptible population? Thorax 49:171-174

6. Kelly FJ, Mudway I, Blomberg A, Frew A, Sandström T 1999 Altered lung antioxidant status in patients with mild asthma. Lancet 354:482-483

7. Van der Vliet A, O'Neill CA, Cross CE, Koostra JM, Volz WG, Halliwell B, Louie S 1999 Determination of low-molecular-mass antioxidant concentrations in human respiratory tract lining fluids. Am J Physiol 276:L289-L296

8. Bui MH, Sauty A, Collet F, Leuenberger P 1992 Dietary vitamin C intake and concentrations in the body fluids and cells of male smokers and nonsmokers. J Nut $122: 312-316$

9. Ogihara T, Okamoto R, Kim HS, Nagai A, Morinobu T, Moji H, Kamegai H, Hirano K, Ogihara H, Tamai H, Mino M 1996 New evidence for the involvement of oxygen radicals in triggering neonatal chronic lung disease. Pediatr Res 39:117-119

10. Moison RMW, De Beaufort AJ, Haasnoot AA, Dubbleman TMAR, Van Zoeren Grobben D, Berger HM 1997 Uric acid and ascorbic acid redox ratios in plasma and tracheal aspirate of preterm babies with acute and chronic lung disease. Free Radica Biol Med 23:226-234

11. Jain A, Metha T, Auld PAM, Rodrigues J, Ward RF, Schwartz MK, Mårtensson J 1995 Glutathione metabolism in newborns: evidence for glutathione deficiency in plasma, bronchoalveolar lavage fluid, and lymphocytes in prematures. Pediatr Pulmonol 20:160-166

12. Gladstone IM, Levine RL 1994 Oxidation of proteins in neonatal lungs. Pediatrics 93:764-768

13. Lenz AG, Costabel U, Maier KL 1996 Oxidised BAL fluid proteins in patients with interstitial lung diseases Eur Respir J 9:307-312

14. Heaney LG, Stevenson EC, Turner G, Cadden IS, Taylor R, Shields MD, Ennis M 1996 Investigating paediatric airways by non-bronchoscopic lavage: normal cellula data. Clin Exp Allergy 26:799-806

15. Law MR, Hackshaw A 1996 Environmental tobacco smoke. Br Med Bull 52:22-34

16. Jarvis MJ, Russell MAH, Feyerabend C, Eiser JR, Morgan M, Gammage P, Gray EM 1985 Passive exposure to tobacco smoke: saliva cotinine concentrations in a representative population sample of non-smoking schoolchildren. BMJ 291:927-929

17. Greenberg RA, Haley NJ, Etzel RA, Loda FA 1984 Measuring the exposure of infants to tobacco smoke: nicotine and cotinine in urine and saliva. N Engl J Med 310:10751078

18. Pacht ER, Kaseki H, Mohammed JR, Cornwell DG, Davis WB 1986 Deficiency of vitamin $\mathrm{E}$ in the alveolar fluid of cigarette smokers. J Clin Invest 77:789-796

19. Morrison D, Rahman I, Lannan S, MacNee W 1999 Epithelial permeability, inflammation, and oxidant stress in the air spaces of smokers. Am J Respir Crit Care Med 1559:473-479

20. Touloumi G, Katsouyanni K, Ziniron D, Schwartz J, Spinx C, DeLeon AP, Tobia A, Quennel, Rabczenko D, Bacharova L, Bisanti L, Vonk JM, Ponka A 1997 Short-term effects of ambient oxidant exposure on mortality: A combient analysis within the APHEA project. Am J Epidemiol 146:177-185

21. Richards RJ 1997 Small particles, big problems. Biologist 44:249-251

22. Hoek G, Schwartz JD, Groot B, Eilers P 1997 Effects of ambient particulate matter and ozone on daily mortality in Rotterdam, the Netherlands. Arch Environ Health 522:455-463

23. Thueston GD, Lippmann M, Scott MB, Fine JM 1997 Summertime haze air pollution and children with asthma. Am J Respir Crit Care Med 155:654-660

24. Xu X, Dochery DW, Wang L 1991 Effects of air pollution on adult pulmonary function. Arch Environ Health 46:198-206

25. Vedal S, Petkau J, White R, Blair J 1998 Acute effects of ambient inhalable particles in asthmatic and non asthmatic children. Am J Respir Crit Care Med 157:1034-1043 26. Ashmore M 1995 Human exposure to air pollutants. Clin Exp Allergy 25:12-22

27. Chao CYH, Tung TCW, Burnett J 1998 Influence of different indoor activities on the indoor particulate levels in residential buildings. Indoor and Built Environment 7:110-121

28. Pilotto LS, Douglas RM 1992 Indoor nitrogen dioxide and childhood respiratory illness. Aust J Public Health 16:245-250

29. Shields MD, Stewart MC, Burns G 1997 Survey of type of home heating and asthma symptoms. Proceedings of the Challenge of Asthma Conference, Tours, France, pp $77-78$

30. Grievink L, Jansen SMA, Van't Veer P, Brunekreef B 1998 Acute effects of ozone on pulmonary function of cyclists receiving antioxidant supplementation. Occup Environ Med 55:13-17

31. Stevenson EC, Turner G, Heaney LG, Schock BC, Taylor R, Gallagher T, Ennis M, Shields MD 1997 Bronchoalveolar lavage findings suggest two different forms of childhood asthma. Clin Exp Allergy 27:1027-1035

32. Chevion S, Berry EM, Kitrossky N, Kohen R 1997 Evaluation of plasma low molecular weight antioxidant capacity by cyclic voltametry. Free Radical Biol Med 22:411-421

33. Ito Y, Ochiai J, Sasaki R, Suzuki S, Kusuhara Y, Morimitsu Y, Otani M, Aoki K 1990 Serum concentrations of carotenoids, retinol, and $\alpha$-tocopherol in healthy persons determined by high-performance liquid chromatography. Clin Chim Acta 194:131144

34. Ikenoya S, Abe K, Tsuda T, Yamano Y, Hiroshima O, Ohmae M, Kawabe K 1979 Electrochemical detector for high-performance liquid chromatography. II. Determination of tocopherols, ubiquinones and phylloquinone in blood. Chem Pharm Bull 27:1237-1244

35. Buss H, Chan TP, Sluis KB, Domigan NM, Winterbourn CC 1997 Protein carbonyl measurement by a sensitive ELISA method. Free Radical Biol Med 23:361-366

36. Buss H, Chan TP, Sluis KB, Domigan NM, Winterbourn CC 1998 Protein carbonyl measurement by a sensitive ELISA method Free Radical Biol Med 24:1352

37. Dhariwal KR, Hartzell WO, Levine M 1991 Ascorbic acid and dehydroascorbic acid measurements in human plasma and serum. Am J Clin Nutr 54:712-716

38. ERS Task Force on Bronchoalveolar Lavage in Children 2000 Bronchoalveolar lavage in children. Eur Respir J 15:217-231

39. Slade R, Crissman K, Norwood J, Hatch GE 1993 Comparison of antioxidant substances in bronchoalveolar lavage cells and fluid from humans, guinea pigs, and rats. Exp Lung Res 19:469-484

40. Cross CE, Van der Vliet A, Louie S, Thiele JJ, Halliwell B 1998 Oxidative stress and antioxidants at biosurfaces: plants, skin, and respiratory tract surfaces. Environ Health Perspect 106(suppl 5):1241-1251

41. Lenz AG, Jorens PG, Mayer B, De Backer W, Van Overveld F, Bossaert L, Maier KL 1999 Oxidatively modified proteins in bronchoalveolar lavage fluid of patients with ARDS and patients at-risk for ARDS. Eur J Respir 13:169-174

42. Rustow B, Haupt R, Stevens PA, Kunze D 1993 Type II pneumocytes secrete vitamin E together with surfactant lipids. Am J Physiol 265:L133-L139

43. Grievink L, Jansen SMA, Van't Veer P, Brunekreef B 1998 Acute effects of ozone on pulmonary function of cyclists receiving antioxidant supplementation. Occup Environ Med 55:13-17

44. Cook DG, Carey IM, Whincup PH, Papacosta O, Chirico S, Bruckdorfer KR, Walker M 1997 Effect of fresh fruit consumption on lung function and wheeze in children. Thorax 52:628-633

45. Braun J, Mehnert A, Dalhoff K, Wießmann KJ, Ratjen F 1997 Different BALF protein composition in normal children and adults. Respiration 64:350-357

46. Homnick DN, Cox JH, DeLoof MJ, Ringer TV 1993 Carotenoid levels in norma children and in children with cystic fibrosis. J Pediatr 122:703-707

47. Honicky RE, Osborne JS III, Apkom CA 1985 Symptoms of respiratory illness in young children and the use of wood-burning stoves for indoor heating. Pediatrics 75:587-593

48. Li XY, Gilmour PS, Donaldson K, MacNee W 1996 Free radical activity and proinflammatory effects of particulate air pollution (PM10) in vivo and in vitro. Thorax 51:1216-1222

49. Donaldson K, Brown DM, Mitchell C, Dineva M, Beswick PH, Gilmour PS, MacNee W 1997 Free radical activity of PM10: iron-mediated generation of hydroxyl radicals. Environ Health Perspect 105:1285-1289

50. Donaldson K, Li XY, MacNee W 1998 Ultrafine (nanometre) particle mediated lung injury. J Aerosol Sci 29:553-560

51. Hatch GE 1995 Asthma, inhaled oxidants, and dietary antioxidants. Clin Nutr 61(suppl 3):625S-630S

52. Cohen HA, Neuman I, Nahum H 1997 Blocking effect of vitamin C in exerciseinduced asthma. Arch Pediatr Adolesc Med 151:367-370 